\title{
ERYTHROCYTE SEDIMENTATION IN CARDIAC FAILURE
}

\author{
L. M. SANGhvi, M.R.C.P.(Lond.), D.T.M. \& H.(ENG.) \\ From the Department of Cardiology, Sawai Man Singh Hospital and Medical College, Faipur, India
}

It is generally believed that the erythrocyte sedimentation (E.S.R.) is retarded and tends to fall to normal when decompensation occurs in rheumatic fever and other heart diseases known to be associated with elevated values. $2,4,5,7,9$ Observations by McGinnis and co-workers, ${ }^{6}$ who excluded patients who presented evidence of other conditions known to lead to elevation of the E.S.R., however, disclosed that the majority of the patients with cardiac failure exhibited elevated values both initially and after recovery from failure. Their data indicated that the E.S.R. tends to be elevated in both acute and chronic congestive failure. Further adequate data on the subject do not seem to be available in the literature. The purpose of this paper is to report a study of the E.S.R. in 190 patients with cardiac failure.

\section{Material and Methods}

One hundred and ninety patients admitted to the hospital for treatment of cardiac failure of varied etiology have been included in this study; patients who died were excluded. There were 124 male and 66 female patients. The age and sex distribution of the patients is given in Table $I$. Rheumatic, emphysema, coronary, and hypertensive heart disease accounted for 34, 20, 19 and $7 \%$, respectively, of the total cases.

E.S.R. determinations were made by the method of Westergren, initially within 24 hours of admis- sion and subsequently at intervals of five to seven days until after the relief of failure; 1.6 cc. of bloodo were drawn from an arm vein in a syringe con- $\frac{3}{6}$. taining $0.4 \mathrm{cc}$. of $3.8 \%$ sodium citrate solution. $\omega$ For the purpose of this study, a first hour reading of $15 \mathrm{~mm}$. or more and/or a second hour reading. of $30 \mathrm{~mm}$. or more was considered definitely pathological and abnormally elevated. In repeat estimations a rise of $5 \mathrm{~mm}$. or more from the initial value was considered a significant elevation. $\overrightarrow{0}$ This elevation was divided into three categories: further rise from initial abnormal values, and rise응 from initial normal values either to abnormal@ values or to one still less than the normal limit $\& f_{\vec{\odot}}$ I $5 \mathrm{~mm}$.

The E.S.R. was also estimated on admission $\frac{\text { s.n. }}{\omega}$. another 125 cardiac patients, but without failure, to serve as control.

\section{Results}

The incidence of abnormally elevated and $\stackrel{\mathcal{Q}}{\mathcal{Q}}$ normal E.S.R. values on admission and of signi- $\overrightarrow{\overrightarrow{0}}$ ficant rises from initial values after relief of failure in various types of heart disease is given in Table 2. The E.S.R. values at the end of one hour in in-dividual cases are given in Table 3. An ab-윽 normally elevated E.S.R. was present on admission.in $96(50 \%)$ cases, with values of $30 \mathrm{~mm}$. or more at the end of one hour in $47(25 \%)$ cases. The highest value recorded was $125 \mathrm{~mm}$. Cases with

Table I

Age and Sex Distribution of 190 Patients according to Type of Heart Disease

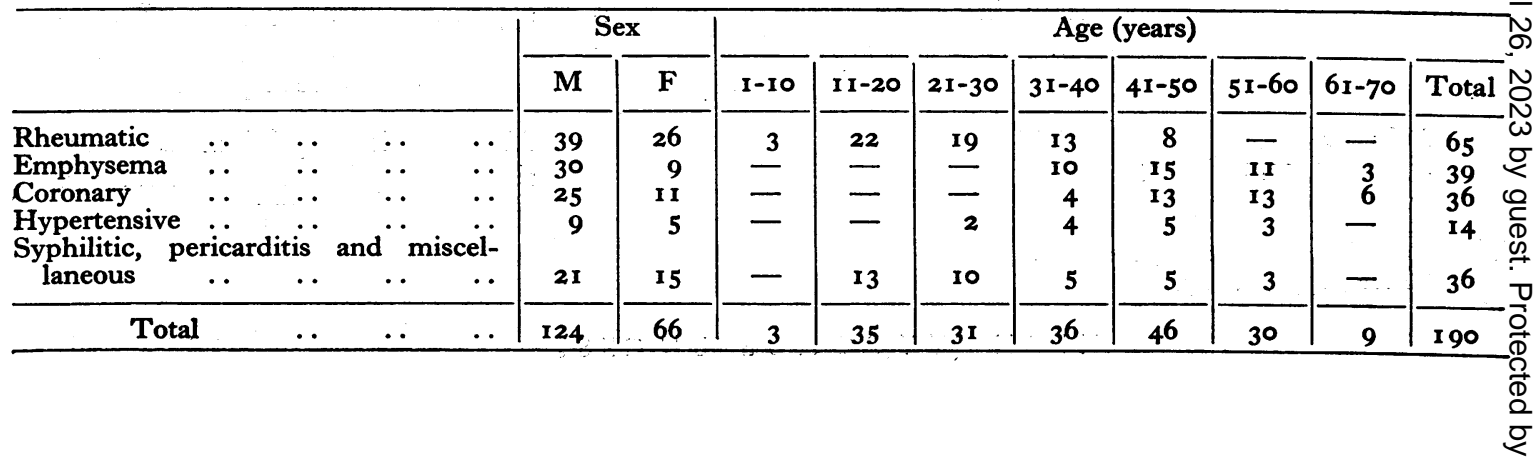


TABLe 2

InCidence of Abnormal and Normal E.S.R. on Admission and of Significant Elevation after Compensation according to Type of Heart Disease

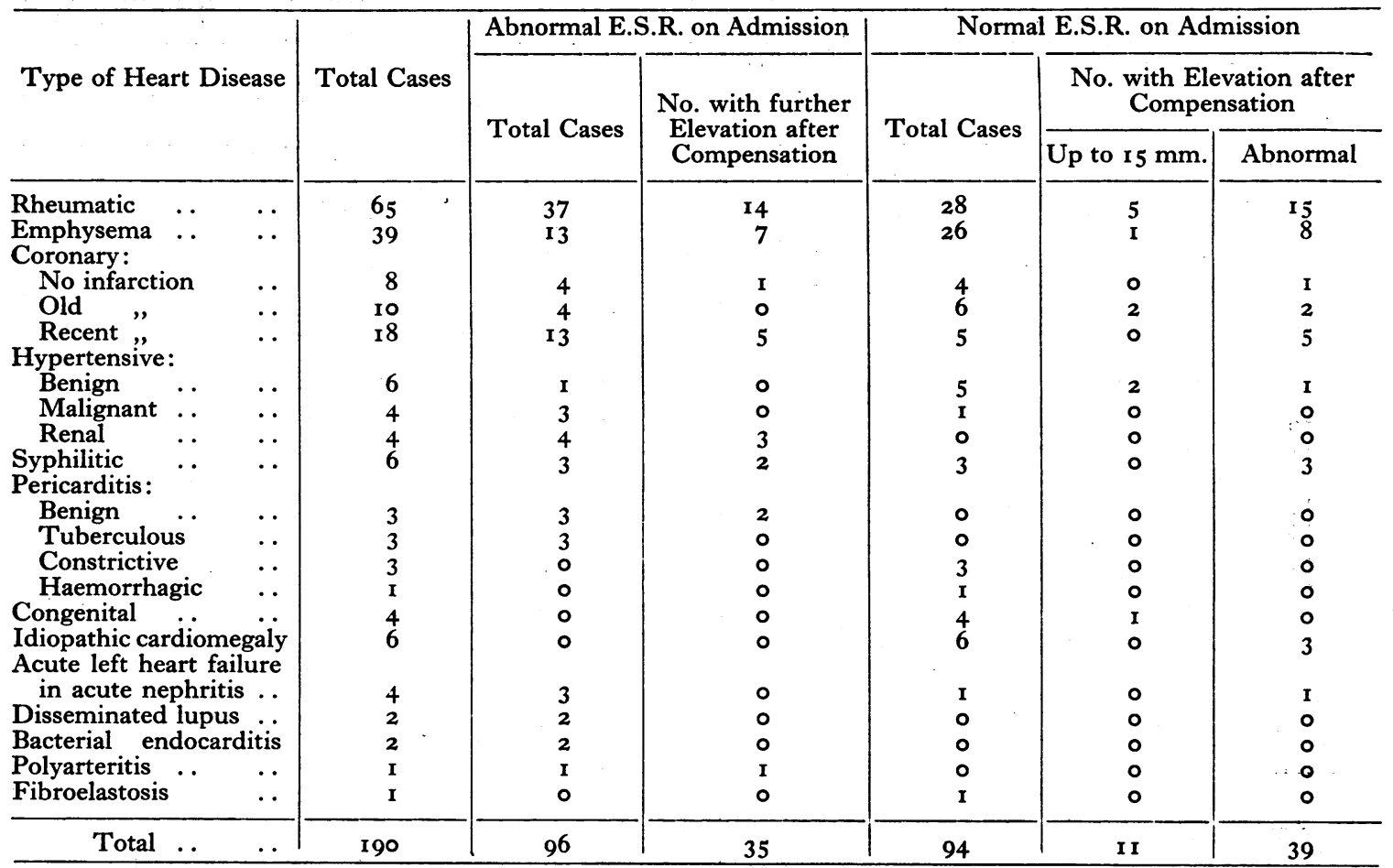

syphilitic heart disease, recent myocardial infarction, malignant and renal hypertension, tuberculous and benign idiopathic pericarditis, and acute nephritis with acute left ventricular failure usually showed abnormal initial values. Cases with benign hypertension, constrictive pericarditis and congenital heart disease usually showed normal values.

The E.S.R. remained normal, initially as well as subsequently, in $55(29 \%)$ cases, including 13 cases of rheumatic heart disease, 18 of emphysema, 7 of coronary heart disease without recent infarction, 4 of benign hypertension, and all the four cases of congenital heart disease and three of constrictive pericarditis. After relief of failure a significant rise of E.S.R. from initial values was seen in $85(45 \%)$ cases. Of the 96 cases with initial abnormal values, there was further elevation in $35(39 \%)$ of them. Of 94 cases with initial normal values, there was abnormal elevation in 39 $(42 \%)$ of them, and there was elevation of $5 \mathrm{~mm}$. or more with values that still remained normal in $11(12 \%)$ of them. The rise of E.S.R. from the initial values varied between five and $78 \mathrm{~mm}$. with an average of $38 \mathrm{~mm}$. Of cases with initial normal and abnormal E.S.R. values, respectively, $70 \%$ and $40 \%$ with rheumatic heart disease and $34 \%$ and $54 \%$ with emphysema heart disease showed significant elevation after relief of failure.

\section{Discussion}

In the present study the influence of cardiac failure and of establishment of compensation on erythrocyte sedimentation has been determined in a variety of heart diseases, known to be associated with both normal as well as abnormal E.S.R. Westergren's method of E.S.R. determination was used as it is considered to be more sensitive sometimes than Wintrobe's method, ${ }^{8}$ superior for serial examinations, ${ }^{3}$ and the method of choice for general purposes. ${ }^{7}$ In 96 cases $(50 \%)$ the E.S.R. remained abnormally elevated despite the presence of cardiac failure, often severe, and values as high as $125 \mathrm{~mm}$. were seen. It was, however, significant that, during decompensation, there was normalization of E.S.R. in 39 cases $(20 \%)$ in whom the E.S.R. became abnormal after compensation, and that significant elevation of E.S.R. after establishment of compensation was noted in a total of $45 \%$ cases. These figures for elevation may be considered as somewhat less than the actual. It is likely that in some cases therapy directed against the etiological factor, or regression of the disease process concomitantly with the 
TABLE 3

E.S.R. Values at the End of One Hour, on Admission and After Compensation. In Each Disease Cases Showing Significant Elevation of E.S.R. After Compensation aRe Numbered First

\begin{tabular}{|c|c|c|c|c|c|c|c|c|c|}
\hline \multirow{2}{*}{$\begin{array}{c}\text { Type of Heart } \\
\text { Disease and } \\
\text { Serial No. }\end{array}$} & \multicolumn{2}{|c|}{ E.S.R. Values } & \multirow{2}{*}{$\begin{array}{l}\text { Type of Heart } \\
\text { Disease and } \\
\text { Serial No. }\end{array}$} & \multicolumn{2}{|c|}{ E.S.R. Values } & \multirow{2}{*}{$\begin{array}{l}\text { Type of Heart } \\
\text { Disease and } \\
\text { Serial No. }\end{array}$} & \multicolumn{3}{|c|}{ E.S.R. Values } \\
\hline & $\begin{array}{l}\text { On Ad- } \\
\text { mission }\end{array}$ & $\begin{array}{l}\text { After } \\
\text { Compen- } \\
\text { sation }\end{array}$ & & $\begin{array}{l}\text { On Ad- } \\
\text { mission }\end{array}$ & $\begin{array}{l}\text { After } \\
\text { Compen- } \\
\text { sation }\end{array}$ & & $\begin{array}{l}\text { On Ad- } \\
\text { mission }\end{array}$ & $\begin{array}{c}\text { After } \\
\text { Compen } \\
\text { sation }\end{array}$ & $n-\frac{\overrightarrow{\vec{F}}}{\frac{\overrightarrow{0}}{0}}$ \\
\hline $\begin{array}{c}\text { Rheumatic } \\
\text { I }\end{array}$ & 2 & 8 & RHEUMATIC- & & & $\begin{array}{l}\text { Old infarction- } \\
\text { contd. }\end{array}$ & & & $\overline{\bar{n}}$ \\
\hline 2 & 3 & 10 & 63 & 90 & 40 & 12 & 3 & I I & $\stackrel{1}{2}$ \\
\hline 3 & 3 & 10 & 64 & 90 & 48 & 13 & I & I & 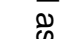 \\
\hline 4 & 3 & 12 & 65 & 112 & 90 & 14 & 15 & 10 & \\
\hline 5 & 4 & 10 & Fyourcame & & & 15 & 15 & 4 & c \\
\hline 6 & 2 & 35 & EMPHYSEMA & & & 16 & 15 & 10 & \\
\hline 8 & 2 & 35 & I & 3 & Io & 17 & 20 & 17 & $\bar{c}$ \\
\hline 8 & 2 & 45 & 2 & 5 & 22 & 18 & 20 & 15 & \\
\hline 9 & 3 & 33 & 3 & 7 & 20 & & & & ৫) \\
\hline 10 & 4 & 34 & 4 & 8 & 42 & Recent & & & (c) \\
\hline II & 5 & 20 & 5 & 9 & 21 & infarction & & & \\
\hline 12 & 5 & 35 & 6 & 10 & 32 & 19 & 2 & 32 & 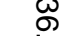 \\
\hline 13 & 5 & 40 & 7 & 10 & 33 & 20 & 3 & 50 & \\
\hline 14 & 5 & 42 & 8 & 10 & 50 & 21 & 5 & 40 & \\
\hline 15 & 5 & 43 & 9 & 13 & 45 & 22 & 5 & 40 & \\
\hline 16 & 8 & 23 & 10 & 15 & 90 & 23 & 10 & 60 & \\
\hline 17 & 10 & 18 & I I & 22 & 90 & 24 & 15 & 40 & O \\
\hline 18 & 10 & 40 & 12 & 25 & 55 & 25 & 16 & 40 & o \\
\hline 19 & I I & 42 & 13 & 30 & 85 & 26 & 22 & 100 & $\rightarrow$ \\
\hline 20 & 12 & 42 & 14 & 45 & 60 & 27 & 30 & 60 & 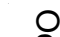 \\
\hline 21 & 15 & 60 & 15 & 60 & 65 & 28 & 65 & 90 & 0 \\
\hline 22 & 15 & 68 & 16 & 60 & 65 & 29 & 16 & 10 & \\
\hline 23 & 16 & 40 & 17 & 2 & 4 & 30 & 20 & 15 & (1) \\
\hline 24 & 16 & 40 & 18 & 3 & 5 & 31 & 25 & 10 & \\
\hline 25 & 17 & 42 & 19 & 3 & 5 & 32 & 25 & 25 응 & \\
\hline 26 & 19 & 24 & 20 & 3 & 5 & 33 & 30 & $23 \leq$ & \\
\hline 27 & 20 & 28 & 21 & 4 & 5 & 34 & 37 & 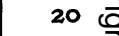 & \\
\hline 28 & 20 & 50 & 22 & 4 & 6 & 35 & 78 & 55 & \\
\hline 29 & 25 & 36 & 23 & $5^{\circ}$ & 5 & 36 & 80 & 60 & \\
\hline 30 & 25 & 62 & 24 & 5 & 3 & & & & \\
\hline 31 & 27 & 80 & 25 & 8 & 7 & SYPHILITIC & & & \\
\hline 32 & 28 & 72 & 26 & 8 & 12 & I & 10 & 60 & \\
\hline 33 & 30 & 42 & 27 & 9 & 5 & 2 & II & 30 & \\
\hline 34 & 50 & 120 & 28 & 9 & 8 & 3 & 13 & 23 & \\
\hline $\begin{array}{l}35 \\
36\end{array}$ & $\begin{array}{l}3 \\
4\end{array}$ & $\begin{array}{l}5 \\
6\end{array}$ & 29 & 10 & 12 & 4 & 20 & $3^{8}$ & \\
\hline $\begin{array}{l}36 \\
37\end{array}$ & $\begin{array}{l}4 \\
5\end{array}$ & $\begin{array}{l}0 \\
4\end{array}$ & 30 & 12 & 8 & 5 & 25 & 82 & \\
\hline 38 & 5 & 5 & 31 & 12 & 10 & 6 & 15 & 15 & \\
\hline 39 & 5 & 7 & 32 & 12 & 10 & & & & \\
\hline 40 & 5 & 8 & 33 & 12 & 3 & PERICARdITIS & & & \\
\hline 4I & 10 & 5 & 34 & 24 & 17 & Benign & & & \\
\hline 42 & 12 & 8 & 35 & 29 & II & I & 35 & 60 & \\
\hline 43 & 18 & 7 & 36 & 35 & 30 & 2 & 45 & 55 & \\
\hline 44 & 19 & 20 & 37 & 38 & 17 & 3 & 32 & 30 & \\
\hline 45 & 20 & 5 & 38 & 40 & 25 & & & & \\
\hline 46 & 20 & 10 & 39 & 45 & 30 & Tuberculous & & & \\
\hline 47 & 20 & 10 & & & & 4 & 25 & 22 & \\
\hline 48 & 22 & 8 & CORONARY & & & 5 & 45 & 35 & \\
\hline 49 & 23 & 12 & No infarction & & & 6 & 89 & 52 & \\
\hline 50 & 23 & 18 & $\mathbf{I}$ & II & 25 & & & & \\
\hline $5 \mathrm{I}$ & 24 & 6 & 2 & 20 & 70 & Constrictive & & & \\
\hline 52 & 25 & 7 & 3 & 2 & 4 & 7 & 5 & 9 & \\
\hline 53 & 25 & 12 & 4 & 2 & 6 & 8 & II & 9 & \\
\hline 54 & 30 & 19 & 5 & 4 & 6 & 9 & 12 & 12 & \\
\hline 55 & 38 & 19 & 6 & 15 & 12 & & & & \\
\hline 56 & 40 & 2 & 7 & 15 & 10 & Haemorrhagic & & & \\
\hline 57 & 40 & 10 & 8 & 20 & 16 & 10 & $\mathbf{1} 3$ & 6 & \\
\hline $5^{8}$ & 52 & 40 & & & & & & & \\
\hline 59 & 55 & 30 & Old infarction & & & HYPERTENSION & & & \\
\hline 60 & 60 & 12 & 9 & 5 & 40 & Benign & & & \\
\hline $6 \mathrm{I}$ & 65 & 12 & 10 & 5 & 48 & I & 2 & 8 & \\
\hline 62 & 75 & 40 & II & 3 & Io & 2 & 3 & I0 & \\
\hline
\end{tabular}




\begin{tabular}{|c|c|c|c|c|c|c|c|c|}
\hline \multirow{2}{*}{$\begin{array}{l}\text { Type of Heart } \\
\text { Disease and } \\
\text { Serial No. }\end{array}$} & \multicolumn{2}{|c|}{ E.S.R.Values } & \multirow{2}{*}{$\begin{array}{c}\text { Type of Heart } \\
\text { Disease and } \\
\text { Serial No. }\end{array}$} & \multicolumn{2}{|c|}{ E.S.R. Values : } & \multirow{2}{*}{$\begin{array}{c}\text { Type of Heart } \\
\text { Disease and } \\
\text { Serial No. }\end{array}$} & \multicolumn{2}{|c|}{ E.S.R. Values } \\
\hline & $\begin{array}{l}\text { On Ad- } \\
\text { mission }\end{array}$ & $\begin{array}{c}\text { After- } \\
\text { Compen- } \\
\text { sation }\end{array}$ & & $\begin{array}{l}\text { On Ad- } \\
\text { mission }\end{array}$ & $\begin{array}{c}\text { After } \\
\text { Compen- } \\
\text { sation }\end{array}$ & & $\begin{array}{l}\text { On Ad- } \\
\text { mission }\end{array}$ & $\begin{array}{c}\text { After } \\
\text { Compen- } \\
\text { sation }\end{array}$ \\
\hline $\begin{array}{c}\text { Benign-contd. } \\
3 \\
4 \\
5 \\
6 \\
\text { Renal } \\
7 \\
8 \\
9 \\
\text { I0 } \\
\text { Malignant } \\
\text { I I } \\
\text { I } 2 \\
\text { I } 3 \\
\text { I } 4 \\
\text { MiscELLANEOUS } \\
\text { Congenital } \\
\text { I }\end{array}$ & $\begin{array}{r}65 \\
82 \\
125 \\
35\end{array}$ & $\begin{array}{r}140 \\
100 \\
140 \\
23\end{array}$ & $\begin{array}{c}\text { Congenital一 } \\
2 \\
3 \\
4 \\
\text { contd. } \\
\text { Idiopathic } \\
\text { cardiomegaly } \\
5 \\
6 \\
7 \\
8 \\
9 \\
\text { 10 } \\
\text { Fibroelastosis } \\
\text { 1 I } \\
\text { Polyarteritis } \\
\text { 12 }\end{array}$ & $\begin{array}{r}3 \\
\text { 10 } \\
\text { 1 } 3 \\
3 \\
4 \\
8\end{array}$ & $\begin{array}{r}20 \\
40 \\
25 \\
4 \\
4 \\
7\end{array}$ & $\begin{array}{l}\text { Systemic } \\
\text { lupus } \\
\text { I3 } \\
\text { I4 } \\
\text { Bazterial } \\
\text { endocarditis } \\
\text { I5 } \\
\text { I6 } \\
\text { Acute left } \\
\text { failure in } \\
\text { acute } \\
\text { nephritis } \\
\text { I } 7 \\
\text { I8 } \\
\text { I9 } \\
20\end{array}$ & $\begin{array}{l}14 \\
25 \\
30 \\
35\end{array}$ & $\begin{array}{l}35 \\
20 \\
30 \\
30\end{array}$ \\
\hline
\end{tabular}

relief of failure, tended to cause decrease or normalization of the E.S.R. and therefore opposes the elevation that might have occurred after compensation. For example, aspirin and penicillin were administered from the beginning in cases of rheumatic heart disease with elevated E.S.R. on admission, but in those with normal E.S.R. on admission they were not administered unless and until the E.S.R. became elevated subsequently. Again, antibiotics were administered routinely to all cases with emphysema heart failure. This may also explain the lesser incidence of subsequent elevation in cases with abnormal initial values in comparison with those with normal initial values. The elevation of E.S.R. after establishment of compensation was often marked, being more than $30 \mathrm{~mm}$. in 39 and more than $40 \mathrm{~mm}$. in 18 cases, the maximum being as high as $78 \mathrm{~mm}$. The average E.S.R. in these 85 cases was $18 \mathrm{~mm}$. on admission and $5^{6} \mathrm{~mm}$. after compensation.

The question arises as to why the E.S.R. rises after the establishment of compensation. It has been the general belief that congestive cardiac failure has a retarding influence on the E.S.R., tending to cause its normalization. McGinnis and co-workers $^{6}$ studied the E.S.R. in patients with heart failure due to arteriosclerotic, hypertensive, and syphilitic heart disease. They apparently considered that the E.S.R. is not elevated in these heart diseases, except in the presence of some complication. They found that the E.S.R. was elevated in most patients, initially as well as after compensation. Speculating on the cause of elevation of the E.S.R. after compensation, they postulated that absorption of the products of tissue necrosis as a result of passive congestion may play a part in the increase of E.S.R. in the period immediately after compensation. In our study the E.S.R. was normal in majority of the patients with benign hypertension. It was elevated in all of the patients with syphilitic aortic valvular disease and in $60 \%$ of those with coronary artery disease without recent infarction. Similar results were obtained in control patients without heart failure. Whether the elevation in these two diseases is due to the heart disease itself or to the presence of some other inapparent concomitant complication is uncertain. The E.S.R. has been stated to be increased in syphilitic aortitis and in certain cases of angina. ${ }^{9}$ In emphysema heart disease the E.S.R. was elevated in $54 \%$ of the cases. In this disease the failure is often precipitated by some respiratory infection which seems to be the most likely explanation for the elevated values. Age or sex appeared to have no relation to the elevation of E.S.R.

In the present series the E.S.R. was normal on admission in $50 \%$ of the cases and after compensation in $40 \%$ of the cases. It remained normal, both initially as well as after compensation, in $29 \%$ of the cases; this included $20 \%$ of the cases with rheumatic heart disease in whom no aspirin or antibiotics were administered, $46 \%$ of those with emphysema heart disease, $40 \%$ of those with coronary heart disease without recent infarction, most of the cases of benign hypertension, and all the cases of congenital heart disease and con- 
strictive pericarditis. The data in our study, therefore, do not support the hypothesis of McGinnis and co-workers ${ }^{6}$ that the E.S.R. tends to be elevated in patients with heart failure. On the contrary, our data strongly support the concept that cardiac failure has a retarding influence on the E.S.R. and that elevation of the E.S.R. after compensation is due to removal of this influence. The cause of this retarding influence requires investigation.

Bland and Jones ${ }^{1}$ found evidence which suggested that acute rheumatic fever is frequently an unrecognizable concomitant of cardiac failure in patients with rheumatic heart disease. In our series also, a high E.S.R. was noted initially in $\mathbf{5 7 \%}$ of the cases, and subsequently in another $23 \%$ of cases. This suggests that the failure is associated with activity of the rheumatic process in a great majority of the cases. The observation is of significance because it suggests that anti-rheumatic therapy is indicated from the beginning in the majority of cases of rheumatic heart disease with failure, even if the initial E.S.R. is normal.

\section{Summary}

Erythrocyte sedimentation was studied, on admission and at intervals until after compensation was established, in 190 patients with congestive cardiac failure.
E.S.R. values were elevated in $50 \%$ of the cases on admission. Significant elevation of E.S.R. 3 values after recovery from failure was observed in $45 \%$ including abnormal elevation from initial. normal values in $20 \%$. The E.S.R. remained= normal, both initially as well as subsequently, in $\stackrel{?}{+}$ $29 \%$.

It is concluded that cardiac failure has a definite $\frac{\bar{\sigma}}{\bar{c}}$ retarding influence on the E.S.R. and tends to cause normalization of E.S.R.

\section{Acknowledgment}

Dr. L. R. Sarin, Superintendent, S.M.S. Hospital, kindly permitted the publication of this report.

\section{REFERENCES} I. BLAND, E. F., and JONES, T. D. (1952), Ann. intern. Med.
37, 1006.

2. DAVIS, L. J. (1946), Practitioner, 157, I 3.

3. GOLDBERG, S., GLYNN, L. E., and BYWATERS, E. G. L' (1952), Brit. med. F., i, 202 4. HARRISON, T. R. (1954), 'Principles of Internal Medicine 'O
pp. 485 and 880 . New York: The Blackiston Co. Inc.

5. KEITH, J. D., ROWE, R. D., and VLAD, P. (1958), ' Heart-

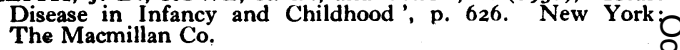

6. MCGINNIS, A. E., LANSCHE, W. E., and GLASER, R. J? (1953), Amer. F. med. Sci., 225, 599.

7. SCHLESINGER, B. (1946), Practitioner, 157, 38

8. SINTON, R. J. (1948), Brit. med. f., i, 391.

9. WHITBY, L. E. H., and BRITTON, C. J. C. (1957) ' orders of the Blood', p. 129. London: J. \& A. Churchill $\mathrm{K}$ d

\section{HAEMATOLOGY}

(Postgraduate Medical Journal)

Price 6s. Od. post free

THE DIFFERENTIAL DIAGNOSIS OF HAEMOL YTIC ANAEMIAS

George Discombe, M.D., B.Sc.

THE RELATIONSHIP BETWEEN GENETIC, NUCLEAR AND SOCIAL SEX

William M. Davidson, M.D., and Shirley Winn, B.Sc.

\section{CELL COUNTS}

J. W. Stewart, M.B., B.S., and P. J. CroslandTaylor, M.B., B.Chir.

THE ASSESSMENT OF PLATELET FUNCTION

A. A. Sharp, M.D., B.Sc.
THE DIAGNOSIS AND MANAGEMENT OF HAEMOPHILIA AND CHRISTMAS DISEASE

M. C. G. Israels, M.Sc., M.D., F.R.C.P., F. Nour-Eldin, Ph.D., M.B., L.S.A., and John F. Wilkinson, M.Sc., Ph.D., M.D., F.R.C.P., F.R.I.C.

\section{HAEMORRHAGIC STATES}

E. K. Blackburn, M.D., F.R.F.P.S

ATYPICAL PERNICIOUS ANAEMIA

Allan Jacobs, M.D.

Published by

THE FELLOWSHIP OF POSTGRADUATE MEDICINE

9, Great James Street, London, W.C.1 